\title{
RESPIRATION DETECTION TOOLS IN HUMAN BASED ARDUINO UNO
}

\author{
Winarno Fadjar Bastari*, Mohamad Habib Amanullah \\ Department of Electrical Engineering \\ University of PGRI Adi Buana Surabaya \\ *Corresponding email address: winarnofbastari@unipasby.ac.id
}

\begin{abstract}
The vital capacity value of the lungs is very influential with the health of the human lungs because with the results the value of the vital capacity of the human lung can be diagnosed as normal or abnormal of the lungs. This study aims to make a means of detecting respiration gas flow rates in humans using an arduino uno-based YF-S201 flow sensor. From the results of data analysis of respiratory gas flow in adult male breathing with ages (20 years - 30 years), (30 years - 35 years), (35 years - 45 years) and (45 years - 50 years) as many as 15 users. there is an error of $3.86 \%$, the value is generated from comparing the output of the equipment made by researchers with other tools of the brand Spirolab with as many as $\mathbf{1 5}$ users of different height and age. From 15 different users there are 2 users with abnormal lung conditions and 13 other users with normal lung conditions. The result of this error occurred because of the 15 users who were less relaxed when exhaling and breathing.
\end{abstract}

Keywords: YF-S201 flow sesnsor, vital capacity of the lungs, lung condition.

\section{INTRODUCTION}

Spirometry is a measuring tool used to measure the flow of air into and out of the lungs. A person who breathes through a spirometry "mouthpiece" needs to be covered in his nose. Respondents who blow are instructed about how to breathe during the procedure. Three breathing maneuvers were tried before determining the procedure data and the highest data from three trials were taken to evaluate breathing. This procedure measures air flow through the principles of electronic or mechanical displacement and uses a microprocessor and recorder to calculate and plot air flow [1], [2], [3].

Vital Capacity is the amount of air (in liters) that comes out of the lungs during normal breathing. Respondents were instructed to inhale and inspire normally to get maximum expiration. The normal value is usually $80 \%$ of the total lung. As a result of lung elasticity and thoracic state, a small amount of air will remain in the lungs after maximal expiration. This volume is called the residual volume (RV) [4], [5], [6].

The purpose of this study is to make hardware devices for detecting gas flow rates of human respiration with YF-S201 flow sensors using Arduino UNO, and to know the performance of YF-S201 flow sensors when respiration gas flow rates in humans [7], [8].

\section{RESEARCH METHODS}

The product design in this study is a tool that uses a powerbank as the main power supply, then uses the YF-S201 flow sensor as a detection of respiration gas flow that is released by the patient, when inhaling and exhaling the respiratory gas in the form of voltage output. On the arduino board given buttons or push buttons up, down, left, and right for the selection of modes as input data for patients in the form of age, gender, and height, the data input function is used to find vital predictive capacity, when all input data has been done, the next menu measures the vital capacity of the patient in a way exhale as strong as possible, breathe in as strong as possible, and breathe normally, the results of vital capacity measurement will appear on the LCD when the results of vital capacity measure appear on the LCD together also appear vital capacity prediction of the results of input of patient data if the results of vital capacity measure $80 \%$ of vital capacity prediction then the patient's condition is normal otherwise if vital capacity measure is less or more than $80 \%$ vital capacity prediction then the patient's condition is abnormal.

The scope of this research is to use the Arduino Uno module as a set of all programs, YFS201 flow sensor to detect respiration gases 
BEST

Journal of Applied Electrical \& Science Technology - University of PGRI Adi Buana

p-ISSN 2715-2871

e-ISSN 2714-5247

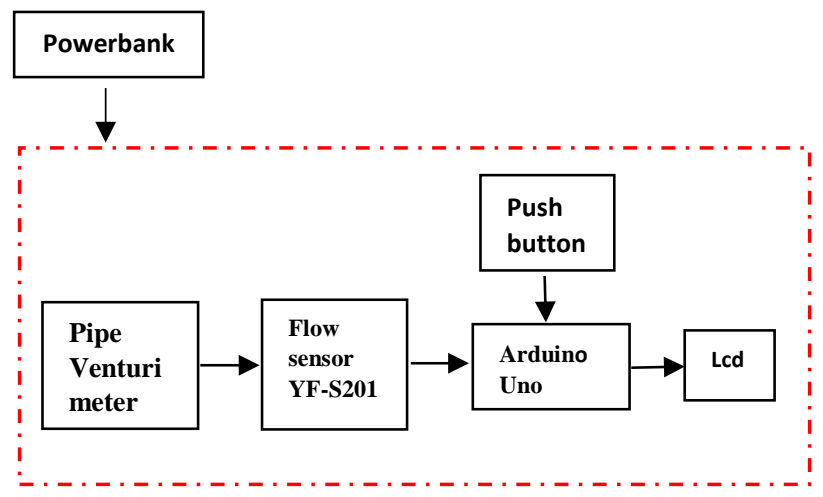

Figure 1. Diagram Block Module

emitted by patients when sucking and exhaling gas, using LCD 2x16 to display the settings menu for age, sex, height, vital capacity prediction results, and measurable vital capacity results Retrieval of data as many as 15 adult male patients with age (20 years - 25 years), (30 years - 35 years), (35 years 45 years) and (45 years - 50 years), and using Powerbank as a power supply.

While the variables used in this research method include the independent variable including the value of human respiration gas, as the dependent variable, the YF-S201 Flow sensor, and the controlled variable, Arduino uno.

\section{RESULTS AND DISCUSSION}

In this section, the test results are collected when the respiration detection gas device is compared with an existing spirolab brand. The data is presented in table 1 , table 2 , and table 3 . Among the test results are.

The data obtained obtained several explanations, among others, namely the average value and the results of the comparison of the vital value of the measuring capacity of researchers with the existing tools spirolab brand. The results of measurements on 15 patients of different ages and height, with measurements of 1 patient 3 times so that the average value of the patient data can be obtained, then it can be calculated what percentage of each patient has an average error of the number of 15 patients. Of the 15 patients, subjects named Novan 30.2 percent and Ryan 16.9 percent VC error was very high and the lowest error was the percentage of patients named Wira 0 percent. So, the average total error of 15 patients is 3.86 percent, so it can be said to be feasible to use

Table 1. Results of Comparison of Vital Capacity of Researcher and Spirolab

\begin{tabular}{|c|c|c|c|c|c|c|c|c|c|}
\hline \multirow[t]{2}{*}{ Name } & \multirow[t]{2}{*}{ VC measure Spirolab } & \multicolumn{3}{|c|}{$\begin{array}{c}\text { Result VC } \\
\text { measure device } \\
\text { researcher }\end{array}$} & \multirow[t]{2}{*}{ mean } & \multirow[t]{2}{*}{ deviation } & \multirow[t]{2}{*}{$\%$ error } & \multirow{2}{*}{$\begin{array}{l}\text { Standard } \\
\text { Deviation }\end{array}$} & \multirow[t]{2}{*}{ Ua } \\
\hline & & $\mathrm{X} 1$ & $\mathrm{X} 2$ & $\mathrm{x} 3$ & & & & & \\
\hline Aji & 3.57 & 3.75 & 3.68 & 3.25 & 3.56 & 0.01 & 0.28 & 2.47 & 1.426 \\
\hline Novan & 4.10 & 3.20 & 3.10 & 2.30 & 2.86 & 1.24 & 30.2 & 0.487 & 0.281 \\
\hline Arik & 3.90 & 3.91 & 3.88 & 3.80 & 3.86 & 0.04 & 1.02 & 0.054 & 0.031 \\
\hline Akbar & 4.20 & 4.77 & 3.98 & 3.84 & 4.19 & 0.01 & 0.23 & 0,5 & 0.288 \\
\hline Toni & 4.01 & 3.98 & 3.95 & 3.90 & 3.94 & 0.07 & 1.74 & 0.141 & 0.081 \\
\hline Nabil & 4.30 & 4.68 & 4.35 & 3.63 & 4.22 & 0.08 & 1.86 & 0.519 & 0.299 \\
\hline Giri & 4.39 & 4.83 & 4.77 & 3.56 & 4.38 & 0.01 & 0.22 & 0.716 & 0.413 \\
\hline wira & 3.60 & 3.84 & 3.67 & 3.30 & 3.60 & 0 & 0 & 0.273 & 0.157 \\
\hline Irul & 4.69 & 4.68 & 4.56 & 4.45 & 4.56 & 0.13 & 2.77 & 0.114 & 0.065 \\
\hline Puji & 3.73 & 3.98 & 3.60 & 3.46 & 3.68 & 0.05 & 1.34 & 0.268 & 0.154 \\
\hline Noldi & 3.40 & 3.60 & 3.40 & 3.18 & 3.39 & 0.01 & 0.29 & 0.209 & 0.120 \\
\hline Radit & 3.56 & 3.82 & 3.56 & 3.29 & 3.55 & 0.01 & 0.28 & 0.258 & 0.148 \\
\hline Ryan & 2.60 & 2.39 & 2.31 & 1.80 & 2.16 & 0.44 & 16.92 & 0.317 & 0.183 \\
\hline Nizam & 3.59 & 3.85 & 3.47 & 3.41 & 3.57 & 0.02 & 0.55 & 0.236 & 0.136 \\
\hline Mifta & 3.40 & 3.56 & 3.40 & 3.21 & 3.39 & 0.01 & 0.29 & 0.173 & 0.099 \\
\hline
\end{tabular}


BEST

Journal of Applied Electrical \& Science Technology - University of PGRI Adi Buana

p-ISSN 2715-2871

e-ISSN 2714-5247

because the tolerance limit is not up to 5 percent of the error value.

\section{CONCLUSION}

Based on the results of planning, module making, writing and data analysis can be concluded as follows:

1. Making this module or tool using the YF-

Table 2. Results of Comparison of Vital Capacity of Researcher and Spirolab

\begin{tabular}{|l|c|}
\hline \multicolumn{1}{|c|}{ Name } & Measurement VC error $\%$ \\
\hline Aji & 0.28 \\
\hline Novan & 30.2 \\
\hline Arik & 1.02 \\
\hline Akbar & 0.23 \\
\hline Toni & 1.74 \\
\hline Nabil & 1.86 \\
\hline Giri & 0.22 \\
\hline wira & 0 \\
\hline Irul & 2.77 \\
\hline Puji & 1.34 \\
\hline Noldi & 0.29 \\
\hline Radit & 0.28 \\
\hline Ryan & 16.92 \\
\hline Nizam & 0.55 \\
\hline Mifta & 0.29 \\
\hline & 3.86 \\
\hline
\end{tabular}

S201 Flow sensor as a detector for respiration gas rate in humans, the LCD character serves to display the vital results of the subject, the keypad as a selector for the selection of measurements, and Arduino Uno as a regulator of all systems. Of these components are synchronized and functioning properly from the comparison of the $\mathrm{VC}$ measuring spirolab measuring instrument with the $\mathrm{VC}$ measuring instrument the researcher measured 15 subjects with different height and age.

2. When measuring 15 subjects with different height and age the performance of the YFS201 Flow sensor can be said to be good or feasible because in the measurement and analysis results show an average error of $3.86 \%$. Of the total measurements of 15 different subjects age, and height.

Table 3. Result Vital Capasity measure, Vital Capasity prediction and lung condition

\begin{tabular}{|c|c|c|c|c|c|c|}
\hline Patient & Name & Old (years) & height $(\mathrm{cm})$ & $\begin{array}{c}\text { VCmeasure device } \\
\text { (liter) }\end{array}$ & $\begin{array}{l}\text { VC Prediction device } \\
\text { (Liter) }\end{array}$ & $\begin{array}{l}\text { Lung } \\
\text { condition }\end{array}$ \\
\hline 1 & Aji & 22 & 158 & 3.56 & 4.47 & Normal \\
\hline 2 & Novan & 24 & 165 & 2.86 & 5.05 & Abnormal \\
\hline 3 & Arik & 23 & 160 & 3.86 & 4.81 & Normal \\
\hline 4 & Akbar & 25 & 167 & 4.19 & 5.13 & Normal \\
\hline 5 & Toni & 30 & 157 & 3.94 & 4.50 & Normal \\
\hline 6 & Nabil & 32 & 168 & 4.22 & 5.03 & Normal \\
\hline 7 & Giri & 31 & 168 & 4.38 & 5.05 & Normal \\
\hline 8 & wira & 35 & 161 & 3.60 & 4.12 & Normal \\
\hline 9 & Irul & 37 & 166 & 4.56 & 4.77 & Normal \\
\hline 10 & Puji & 40 & 162 & 3.68 & 4.54 & Normal \\
\hline 11 & Noldi & 42 & 159 & 3.39 & 3.67 & Normal \\
\hline 12 & Radit & 45 & 160 & 3.55 & 4.23 & Normal \\
\hline 13 & Ryan & 46 & 165 & 2.16 & 3.20 & Abnormal \\
\hline 14 & Nizam & 48 & 171 & 3.57 & 4.26 & Normal \\
\hline 15 & Mifta & 50 & 170 & 3.39 & 3.86 & Normal \\
\hline
\end{tabular}




\section{ACKNOWLEDGMENT}

Acknowledgments and awards need to be conveyed to various parties who have provided assistance in the form of guidance, direction, advice, support and convenience from the beginning to the end of the preparation of Scientific Articles. Also, thanks to PGRI Adi Buana University Surabaya Faculty of Industrial Technology especially the Electrical Engineering study program, which has provided laboratory facilities for the completion of writing this article.

\section{REFERENCE}

[1] Bintoro MW.2014. Sistem Otomasi pengisian dan penghitungan Jumlah gallon pada depot air isi ulang berbasis Mikrokontroller Atmega8535, Jurnal fisika Unand, Vol.3 No.3 Juli 2013: 148-155

[2] Faramida RN.2015. Rancang Bangun Alat Kendali Volume Fluida Mengganti Pewaktu Berbasis Mikrokontroller Atmega8..(Skripsi) Jurusan Fisika, Fakultas Sans danTeknologi,Universitas Islam Negeri Sunan Kalijaga Yogyakarta.

[3] Fraden J.2010. Handbook of Modern Phisycs, design And Aplication,fouthedition.United State of America: springer-Verlag

[4] Gamong WF.2010. Buku Ajar fisiologi kedokteran.EGC Emergency Arcan Buku Kedokteran.

[5] Kosim MS.2009. Deteksi Dini dan Manajemen Gangguan Napas Pada Neonatus Sebagai Apilkasi PONEK (Pelayanan Obstetri Neonatal Emergency Komprehensif).Semarang:UNDIP

[6] Muhajir K.2009. Karakterisasi Aliran fliuda gas-pipa melalui sudden contraction. Jurnsl teknologi, vol 2 no. 2 desember 2009:176-184

[7] Planzer. 2000. Vital lung capacity with body weight, longitudinal circumference dimensions

[8] Syaifuddin H.2011. Sistem pernafasan:Assesment, Patofisiologi dan Terapi Gangguan Pernafasan: Malang:FK Universitas Brawijaya 